\title{
Swedish Professionals and Gender Inequalities
}

\author{
CHARLES W. MUELLER \\ University of lowa \\ SAROSH KURUVILLA \\ Cornell University \\ RODERICK D. IVERSON \\ University of Melbourne
}

\begin{abstract}
The match of ideology and policy regarding gender equality in a corporatist society like Sweden should result in reduced gender inequality in access to supervisory authority and in earnings. The magnitude and form of this inequality is studied for a national sample of 1,359 full-time members of the professional union SACO in 1987-88. We find that Swedish professional women have only 68\% of the supervisory positions that men have and $77 \%$ of the earnings that men have. These differences are not explained by process differences; human capital, family status, and structural variables generally produce access to authority and earnings similarly for men and women. Although there are mean resource differences in human capital and structural resources that disadvantage women and thus partly explain the gaps, the major factor explaining these gender gaps is occupational segregation. However, even when men and women are equalized on occupation and other explanatory variables, a gap favoring men is still found.
\end{abstract}

Research on gender differences in the labor market outcomes of earnings (e.g., Bielby \& Bielby 1992; Featherman \& Hauser 1976; Jacobs \& Steinberg 1990; Parcel \& Mueller 1983) and authority position (e.g., Mueller \& Parcel 1986; Reskin \& Ross 1992; Wolf \& Fligstein 1979; Wright et al. 1982) has dominated the U.S. stratification literature for several decades. What has been the most informative recently, however, are studies of other societies and cross-cultural comparisons of gender differences (e.g., Brinton 1988, 1989; Loscocco \& Kalleberg 1988; Rosenfeld \& Kalleberg 1990; Verba et al. 1987). Out of this recent cross-cultural research has emerged the recognition that one society, Sweden, is unique in a number of ways. ${ }^{i}$

Sweden has been called a "corporatist society" (Goldthorpe 1984; Rosenfeld \& Kalleberg 1990) and is characterized by the "institutionalization of centralized bargaining among the government, 
employers, and labor in an attempt to curb the power of employees in collective bargaining" (Rosenfeld \& Kalleberg 1990:73). This is contrasted with dualist societies, like the U.S., where unions are weaker and the employers, with government support, perpetuate segmentation and the freer operation of market forces. As a consequence, economic equality in general is expected to be greater in the corporatist societies.

The working hypothesis has been that if gender equality is to be found, it should be found in Sweden because of the coexistence of ideology and policy designed to produce equality. However, there now exists evidence (Aberg, Selén \& Tham 1987; Hedstr6m 1988; Rosenfeld \& Kalleberg 1990; Verba et al. 1987) that pay equality does not exist; Swedish women lag behind their male counterparts. There are fewer data, however, on gender differences in pay within the Swedish professional ranks and few data on gender differences in access to positions of authority among professionals. If we are to better understand gender inequalities, then it is important not only to gather data from different cultural contexts, but to carefully examine these inequalities in contexts where the conditions are "stacked" to produce equality. With this in mind, we examine gender differences in pay and access to authority of Swedish professionals.

\section{Authority and Earnings as Outcomes}

The study of access to authority positions and differences in earnings requires little justification. Not only is such research inextricably connected to classical theoretical arguments from Marx, Weber, the functionalists, and Dahrendorf about economic and power dimensions of stratification, it also has practical and policy implications for concerns such as discrimination and equality of opportunities.

Earnings, without question, is the employment outcome most often used by both economists and sociologists in assessing gender inequality in the work force. Being in a position of authority to control and direct the work of others is a feature of industrialized societies that recently has become a focus of attention with the revival of Marxist interpretations of modem stratification forms. The significance of authority position in helping identify an employee's position in a society's stratification structure is now well established (Mueller, Parcel \& Tanaka 1989; Reskin \& Ross 1992; Robinson 1984; Wolf \& Fligstein 1979; Wright \& Perrone 1977). Control over others is a feature of the employment relationship that can be based on both achieved and ascribed characteristics (Kluegel 1978) and thus may validly be used to assess gender inequality. 


\section{Women as a Part of the Swedish Labor Force}

Sweden's well-known goal of low unemployment has only recently been directed at female participation, and in particular, the participation of married women. From 1950 to 1975 there was an almost 300\% increase in the employment of married women (Ahlqvist 1979). In 1968, out of all Swedish women between 20 and 64 years of age, 56\% were employed. By 1980, this figure had increased to $77 \%$. For men in the same age group, the employment level stayed at $90 \%$ during the same period.

Progress toward employment equality of men and women has its roots in Sweden's progressive plan to establish equality between the sexes (Intons- Peterson 1988). This has involved "universal" labor market frameworks, coherent family policies (e.g., 1982 Social Service Act) and explicit legislation on gender equality. In 1979 the government enacted the Act on Equality, which forbids an employer from discriminating against an employee on account of gender. The legislation ensured that men and women should enjoy equal opportunities for employment, training, and on-the-job development, including equal pay for work of equal value. In addition, Sweden's legislated comprehensive parental insurance plan has been significant in affording men and women the same practical opportunities for participating in parenthood.

It is this coexistence of strong ideology and policy about equality that led researchers like Rosenfeld and Kalleberg (1990) to expect smaller earnings gaps in Sweden and overall weaker effects of variables like marriage, children, occupational distributions, internal labor market position and unions on these gaps.

\section{Explaining Authority and Earnings Outcomes}

A part of our strategy involves examining the gap between men and women in to authority positions and in labor earnings. However, the unadjusted estimates of these gaps are likely biased because men and women differ in characteristics that are related to the outcome variables. These variables to be controlled come from the human capital and status attainment traditions (e.g., Becker 1964; Blau \& Duncan 1967; Featherman \& Hauser 1978), and more recently, from the new structuralists who argue that employees are differentially located in varying work environments that differ in the levels of the outcome variables (see Hodson 1989; Kalleberg \& Berg 1987). Although these variables come mainly from U.S. models and data, Hedstr6m (1988) relies on a similar model for his study of stratification in 
Sweden and even refers to the variables as coming from an individual perspective and a structural perspective.

The human capital variables are education, total work experience, work experience within the firm, and work experience within the union. Both the positive linear effects of these forms of experience and the deterioration of the skills and knowledge associated with types of experience are taken into account. These are more universalistic criteria that employers use for granting supervisory authority and differentially allocating pay across employees. In an egalitarian society their effects (regression coefficients) should be the same for men and women (even though the mean differences may be different). Similarly, although the components of family status - marital status and number of children are more often viewed as determinants of the degree of labor force participation than of pay and access to authority, they are acknowledged to be important in Sweden, where both ideology and policy have been altered to reduce the differential impact these have by gender. If the policies have been effective, they are expected to have little impact, either additive or nonadditive.

We examine structural features of the employment situation at three levels. First, we expect employment in the private sector rather than the public sector to positively increase earnings. Second, we expect the size of the employing establishment to be positively related to pay and to chances of having a supervisory position. These two structural features are important from the "new structuralist" perspective that firms in different economic sectors provide different reward and benefit structures for employees. Third, to the extent that occupational segmentation by gender exists within the professional ranks, different pay schedules and authority structures across professional occupations could account for a part of the male and female differences (Baron \& Bielby 1985; Jacobs 1989a, 1989b; Rosenfeld \& Spenner 1992). Existing data (Ahlqvist 1979; Aberg 1987; Rosenfeld \& Kalleberg 1990) show occupational segregation in Sweden by gender across a broad range of occupations, including the professions, but there is essentially nothing known about how this influences gender differences in access to authority and pay within the professional ranks.

As is described below our sample is of union members only. In their study across all occupations Rosenfeld and Kalleberg (1990) find that union membership in Sweden reduces the earnings gaps between men and women. Therefore, because of the unique combination of ideology and policy, the fact that union members are studied and the fact that the sample is of highly educated professionals who are likely to push for gender equality, the inequality is expected to be low. More precisely, we expect inequality to be less for pay than for access to supervisory authority. Pay equality by gender is an explicit component of Swedish policy. In addition, and as is argued by Fernandez (1975), Kanter (1977), 
Kluegel (1978), and Mueller, Parcel, and Tanaka (1989), access to positions of authority is susceptible to particularistic manipulation, where vaguely defined and unmeasured criteria such as loyalty, good character, and leadership potential are applied. In such instances, Kanter (1977) argues that homosocial reproduction occurs and men see to it that men are advanced under the guise of loyalty and good character. This suggests, then, that the gender effect would be more marked and that the residual, often identified as discrimination, would be larger for supervisory authority than for earnings.

\section{Data and Methods}

The data were collected prior to the recent shift in power to more conservative control. They represent a 1987-88 national sample of union members who are affiliated with the Swedish Confederation of Professional Associations (SACO), the major professional union federation in Sweden. The professions represented by SACO are diverse and include occupations such as university professors, doctors, lawyers, clergy, military officers, economists, and social workers. A list of the 25 specific unions subsumed under the confederation of SACO is provided in the Appendix.i Union density in Sweden is high at about $80 \%$ across blue-collar, white-collar, and professional employees in 1990 . Of all employed union members in 1990, about 10\% were members of SACO (53\% were in LO, the blue-collar union and $37 \%$ in TCO, the white collar union).

A random sample of 3,000 members was sent questionnaires. Responses from 1995 were received within a period of one month, yielding a return rate of $66 \%$. No reminders were sent and further responses were not elicited. After restricting the sample to full-time wage or salary employees and using listwise deletion for missing data on all variables in the analysis, 1,359 (400 females and 959 males) remained for the analysis. iii The analysis of only full-time employees was necessary because data on the actual number of hours worked were not collected, thus confounding comparisons when those who said they did not work full-time were included.

The dependent variables for the analysis are supervisory status and pay.

Supervisory status is a dummy variable coded 1 for those who say they supervise other employees and 0 for those who do not supervise. Pay is monthly salary in Swedish kroner, with one U.S. dollar equaling six kroner. Midpoints were assigned to the seven pay categories and Pareto estimates for the beyond25,000 category were obtained separately for men and women. Because this upper value was not extreme $(32,651$ for men and 33,842 for women), the distribution is not very skewed, thus allowing us to use actual (rather than logged) salary. 
Human capital resources are measured in several ways. Consistent with Rosenfeld and Kalleberg (1990), age and age squared are included as proxies for labor force experience and deterioration, respectively. Similarly, firm tenure, firm tenure squared, union tenure and union tenure squared are included to capture the effect of seniority and within-firm and within-union skills and achievements. Education is measured with dummy variables (no college, B.A., M.A., and Ph.D) in order to capture nonlinear effects. ${ }^{\text {iv }}$ Position in the economic structure of the society is measured by establishment size (natural log) and by a dummy variable for employment in the private sector (as opposed to the public sector). Union/occupation is measured by a series of dummy variables representing the occupationspecific union to which the employee belongs. ${ }^{\vee}$ As may be seen in the Appendix, using the unions as the categories does not entirely capture the occupation segregation; there still exists some occupational heterogeneity within the categories. A dummy variable for marital status (coded 1 for married or cohabiting) is included to capture the employee's marital status, while number of children measures the number of children currently living at home.

The analysis of gender differences in supervisory position is conducted with logistic regression and is supplemented with ordinary least square (OLS) estimates. The analysis of pay uses OLS multiple regression and analysis of covariance. Regression decomposition results are also reported.

\section{Results}

\section{MEAN DIFFERENCES}

Table 1 presents descriptive data for the total sample and several meaningful subsamples: (1) those employed in the private sector vs. those employed in the public sector and (2) those aged 40 and younger vs. those aged older than 40 . It is possible that government and union policies are enforced more in the public sector. In addition, gender differences can be expected to be smaller among the younger employees because they will have been affected more by the feminist movement of the 1960s and 1970s (Davis \& Robinson 1991).

The data show that female professionals, regardless of industrial sector or age, are less likely to occupy supervisory positions (.196 difference for the total) and are paid lower monthly salaries than their male counterparts $(3,890$ kroner difference for the total). Women earn $77 \%$ of what their male counterparts earn. With only a few exceptions, males are "advantaged" relative to women on human capital and structural resources (many of these differences are not significant for the subsamples, but 
the directions rather consistently favor males). Such data suggest, of course, that the gender gap will be at least partly explained by these differences.

The data on marriage and family show a clear pattern. Female professionals are less likely married than are their male counterparts, although we see that this difference is not significant for those younger than 41 and those employed in the private sector. Finding no gender differences in the 40-and-younger category is consistent with the fairly recent attempts to eliminate marital status as a deterrent to working among women. For all comparisons, women in the professions have fewer children at home than men do. These data are undoubtedly a function of professional women being less likely to be married, supporting the stereotypical picture of female professionals as individuals who give up marriage and children to undertake full-time employment.

We also note that pay, regardless of gender, is higher in the private sector and higher among the older employees. The same is true for holding a supervisory position. In addition, the gender gaps for both pay and supervisory position are greater in the private sector and among the older employees. These findings are consistent with expectations that equality is more likely to appear among younger cohorts and in the public sector.

\section{EXPLAINING SUPERVISORY AUTHORTY DIFFERENCES}

As was shown in Table 1 almost 20\% more men than women are in supervisory positions. This, of course, is likely not a pure gender effect and could be due to (1) women having characteristics (e.g., less experience) that do not qualify them to assume positions of authority, or (2) to these characteristics not being "translated" into positions of authority at the same rate as for their male counterparts. This second explanation may be assessed by checking for gender interactions with the explanatory variables. For supervisory authority the overall interaction tests for equations 1 and 2 (as identified in Table 2) were not significant, but once all 30 explanatory variables were included (equation 3 ), the logistic regression test for the interactions was significant $\left(X^{2}=47.94 ; 30 \mathrm{df}\right)$. An examination of all 30 interaction terms (data not shown) revealed only three significant interactions: (1) male teachers have greater access to authority than female teachers, (2) male social workers have greater access to authority than their female counterparts, and (3) employment in the private sector gives men greater access to positions of authority than women. Equation 3 presents the logistic results when just these three interactions are included in the equation. 
Referring to the logistic regression results in Table 2, equation 1 predicts supervisory authority with gender, human capital variables, and marriage and children variables. Equation 2 adds the two economic sector variables and equation 3 adds the set of dummy variables for professional union. Looking at equation 3 we see that education has no net effect, suggesting that although a higher degree is necessary to enter a profession (and associated union), advancements into positions of authority, once one is a professional, are based on criteria other than education. What some of these criteria are is revealed by the other significant coefficients in this equation. On one hand, we see that both age and organizational tenure have nonlinear effects, with the likelihood of having authority first increasing, but then declining. On the other hand, access to authority increases but does not then decline with tenure in the union. This set of findings suggests that unions reward seniority in a linear fashion, whereas the firms allocate positions of authority based on the assumption that skills deteriorate over time.

Unexpectedly, being married is positively related to gaining authority; it has usually been found to have a negative effect. But we find that female professionals in Sweden are not hindered in access to supervisory authority relative to men because of their marital status or the number of children they have. Family variables were expected (Rosenfeld \& Kalleberg 1990) to have weakened negative effects in Sweden due to the policies designed to keep family responsibilities from disadvantaging women. Our findings are consistent with this.

Positions of supervisory authority are not differentially distributed on the basis of the size of the employing firm. However, which profession (and therefore professional union) one has chosen does influence the person's chances of having supervisory authority (see the significant union coefficients in equation 3 of Table 2). This means some professions inherently have more supervisory positions than others. Finally, the three significant interactions described above are shown in equation 3.

The magnitudes of the effects of these variables on gender differences may be revealed with estimates of the adjusted gender gap as given in Table 2. The original gap was .196. Using OLS estimation procedures we see that $21 \%$ of the gap (.042) is due to the lower levels of human capital that women have and to the family characteristics that reduce their access to positions of authority. ${ }^{\text {vi }}$ Next, considering the differential distribution of men and women in the economy, an additional $10 \%$ of the gap is explained because a smaller proportion of women than of men are in the private sector and in larger firms. Finally, an additional $26 \%$ of the gap is accounted for by the fact that women are more likely than men to be in professional occupations where relatively few positions of authority are available. ${ }^{\text {vii }}$ The magnitude of this is especially impressive, because it is a conservative estimate of the impact of occupational segregation; by entering human capital, family, and economic structure variables 
first, the covariation of occupation with these has already been attributed to these variables and not to an occupational union. The most liberal estimate of the impact of occupational segregation comes from an equation that includes just the dummy variable for gender and the set of dummies for professional union. In this equation, the gap is reduced by $35 \%$ from .196 to .128. Gender segregation in access to particular professional occupations is a very significant factor in women's lower likelihood of holding supervisory positions. This also is reflected in the R2s presented in Table 2. A large increment in unique explained variance is seen with the addition of occupational unions to the model.

TABLE 1: Descriptive Data: Means and Standard Deviations for Full-Time Employed Members of SACO

\begin{tabular}{|c|c|c|c|c|c|c|}
\hline & \multicolumn{6}{|c|}{ Industrial Sector } \\
\hline & \multicolumn{2}{|c|}{ Total } & \multicolumn{2}{|c|}{ Public } & \multicolumn{2}{|c|}{ Private } \\
\hline & Female & Male & Female & Male & Female & Male \\
\hline Monthly wages ${ }^{b}$ & $\begin{array}{l}12.82^{* * *} \\
(4.38)\end{array}$ & $\begin{array}{c}16.71 \\
(6.22)\end{array}$ & $\begin{array}{l}12.60 \\
(4.46)\end{array}$ & $\begin{array}{l}15.95 \\
\text { (5.91) }\end{array}$ & $\begin{array}{l}13.62^{\star * * *} \\
(4.04)\end{array}$ & $\begin{array}{c}18.83 \\
(6.54)\end{array}$ \\
\hline Supervises others & $\begin{array}{c}.41^{\star \# \star *} \\
(0.49)\end{array}$ & $\begin{array}{c}.60 \\
(0.49)\end{array}$ & $\begin{array}{l}.41^{\star \star \star ~} \\
(0.49)\end{array}$ & $\begin{array}{c}.58 \\
(0.49)\end{array}$ & $\begin{array}{l}.41^{\text {tht }} \\
(0.49)\end{array}$ & $\begin{array}{c}.65 \\
(0.48)\end{array}$ \\
\hline Age & $\begin{array}{c}40.83^{*} \\
(10.08)\end{array}$ & $\begin{array}{l}42.23 \\
(9.55)\end{array}$ & $\begin{array}{l}41.99^{*} \\
(10.08)\end{array}$ & $\begin{array}{l}43.50 \\
(9.36)\end{array}$ & $\begin{array}{l}36.72^{* \star *} \\
(9.00)\end{array}$ & $\begin{array}{c}39.88 \\
(9.46)\end{array}$ \\
\hline No college & $\begin{array}{c}.03^{* * *} \\
(0.17)\end{array}$ & $\begin{array}{c}.10 \\
(0.30)\end{array}$ & $\begin{array}{l}.02^{*+*} \\
(0.16)\end{array}$ & $\begin{array}{c}.09 \\
(0.29)\end{array}$ & $\begin{array}{r}.04^{*} \\
(0.21)\end{array}$ & $\begin{array}{c}.11 \\
(0.31)\end{array}$ \\
\hline Bachelor's degree & $\begin{array}{c}.15^{\star \star} \\
(0.36)\end{array}$ & $\begin{array}{c}.10 \\
(0.30)\end{array}$ & $\begin{array}{r}.16^{*} \\
(0.36)\end{array}$ & $\begin{array}{c}.10 \\
(0.31)\end{array}$ & $\begin{array}{c}.14 \\
(0.34)\end{array}$ & $\begin{array}{r}.10 \\
(0.30)\end{array}$ \\
\hline M.A. degree & $\begin{array}{c}.76^{m+*} \\
(0.42)\end{array}$ & $\begin{array}{r}.66 \\
(0.47)\end{array}$ & $\begin{array}{l}.76^{*+*} \\
(0.43)\end{array}$ & $\begin{array}{c}.65 \\
(0.48)\end{array}$ & $\begin{array}{c}.77 \\
(0.42)\end{array}$ & $\begin{array}{r}.69 \\
(0.46)\end{array}$ \\
\hline Ph.D. degree & $\begin{array}{l}.05^{*} \\
(0.22)\end{array}$ & $\begin{array}{c}.14 \\
(0.34)\end{array}$ & $\begin{array}{l}.05+\ldots \\
(0.23)\end{array}$ & $\begin{array}{c}.15 \\
(0.36)\end{array}$ & $\begin{array}{r}.04^{*} \\
(0.21)\end{array}$ & $\begin{array}{r}.10 \\
(0.30)\end{array}$ \\
\hline Union tenure & $\begin{array}{l}10.69^{\star \star *} \\
(8.20)\end{array}$ & $\begin{array}{l}12.42 \\
(8.80)\end{array}$ & $\begin{array}{l}11.13^{\text {** }} \\
(8.16)\end{array}$ & $\begin{array}{l}13.22 \\
(8.99)\end{array}$ & $\begin{array}{c}9.11 \\
(8.21)\end{array}$ & $\begin{array}{l}10.95 \\
(8.25)\end{array}$ \\
\hline Firm tenure & $\begin{array}{l}7.04^{\star \star \star} \\
(7.00)\end{array}$ & $\begin{array}{c}9.13 \\
(7.88)\end{array}$ & $\begin{array}{l}7.50 \text { * } \\
(7.02)\end{array}$ & $\begin{array}{c}9.96 \\
(8.04)\end{array}$ & $\begin{array}{l}5.38 \\
(6.74)\end{array}$ & $\begin{array}{c}7.60 \\
(7.34)\end{array}$ \\
\hline Firm size (logged) & $\begin{array}{l}4.46^{\text {tw* }} \\
(1.66)\end{array}$ & $\begin{array}{c}5.02 \\
(1.82)\end{array}$ & $\begin{array}{l}4.38^{* \star} \\
(1.54)\end{array}$ & $\begin{array}{c}4.75 \\
(1.66)\end{array}$ & $\begin{array}{l}4.73^{* * *} \\
(2.01)\end{array}$ & $\begin{array}{c}5.51 \\
(1.99)\end{array}$ \\
\hline Private sector & $\begin{array}{l}.22^{\star * * *} \\
(0.42)\end{array}$ & $\begin{array}{c}.35 \\
(0.48)\end{array}$ & - & $\overline{-}$ & $\overline{-}$ & $\overline{-}$ \\
\hline Married & $\begin{array}{c}.73^{* 4} \\
(0.44)\end{array}$ & $\begin{array}{c}.82 \\
(0.38)\end{array}$ & $\begin{array}{l}.72^{\star \star \star} \\
(0.45)\end{array}$ & $\begin{array}{c}.83 \\
(0.38)\end{array}$ & $\begin{array}{c}.75 \\
(0.44)\end{array}$ & $\begin{array}{r}.82 \\
(0.39)\end{array}$ \\
\hline Number of children & $\begin{array}{l}.90^{\text {twm }} \\
(1.05)\end{array}$ & $\begin{array}{c}1.29 \\
(1.17)\end{array}$ & $\begin{array}{l}.94^{* \# *} \\
(1.07)\end{array}$ & $\begin{array}{c}1.33 \\
(1.17)\end{array}$ & $\begin{array}{l}.77^{* * *} \\
(0.98)\end{array}$ & $\begin{array}{c}1.21 \\
(1.16)\end{array}$ \\
\hline $\mathbf{N}$ & 400 & 959 & 313 & 622 & 87 & 337 \\
\hline$(\mathrm{N}=1,359)$ & & & & & & \\
\hline
\end{tabular}


TABLE 1: Descriptive Data: Means and Standard Deviations for Full-Time Employed Members of SACO' (Continued)

\begin{tabular}{|c|c|c|c|c|}
\hline & & & & \\
\hline & 40 and & Younger & Older $t$ & han 40 \\
\hline & Female & Male & Female & Male \\
\hline Monthly wages ${ }^{b}$ & $\begin{array}{l}11.83 \\
(3.78)\end{array}$ & $\begin{array}{c}14.70 \\
(5.15)\end{array}$ & $\begin{array}{l}13.82 \\
(4.72)\end{array}$ & $\begin{array}{c}18.27 \\
(6.53)\end{array}$ \\
\hline Supervises others & $\begin{array}{c}.39 * * * \\
(0.49)\end{array}$ & $\begin{array}{c}.56 \\
(0.50)\end{array}$ & $\begin{array}{c}.42^{+* * *} \\
(0.50)\end{array}$ & $\begin{array}{r}.64 \\
(0.48)\end{array}$ \\
\hline Age & $\begin{array}{l}32.47^{*} \\
(5.19)\end{array}$ & $\begin{array}{c}33.47 \\
(4.46)\end{array}$ & $\begin{array}{l}49.19 \\
(6.03)\end{array}$ & $\begin{array}{c}49.02 \\
(6.39)\end{array}$ \\
\hline No college & $\begin{array}{c}.02 \text { t* } \\
(0.12)\end{array}$ & $\begin{array}{c}.07 \\
(0.26)\end{array}$ & $\begin{array}{c}.04 * * \\
(0.20)\end{array}$ & $\begin{array}{c}.12 \\
(0.32)\end{array}$ \\
\hline Bachelor's degree & $\begin{array}{r}.16^{\star} \\
(0.36)\end{array}$ & $\begin{array}{c}.09 \\
(0.28)\end{array}$ & $\begin{array}{c}.15 \\
(0.36)\end{array}$ & $\begin{array}{c}.11 \\
(0.32)\end{array}$ \\
\hline M.A. degree & $\begin{array}{c}.80 \\
(0.40)\end{array}$ & $\begin{array}{c}.76 \\
(0.43)\end{array}$ & 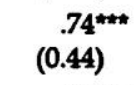 & $\begin{array}{r}.59 \\
(0.49)\end{array}$ \\
\hline Ph.D. degree & $\begin{array}{r}.04^{*} \\
(0.18)\end{array}$ & $\begin{array}{c}.08 \\
(0.27)\end{array}$ & $\begin{array}{c}.07^{\text {*at }} \\
(0.26)\end{array}$ & $\begin{array}{c}.18 \\
(0.38)\end{array}$ \\
\hline Union tenure & $\begin{array}{r}6.27^{*} \\
(4.41)\end{array}$ & $\begin{array}{c}7.35 \\
(5.47)\end{array}$ & $\begin{array}{c}15.10 \\
(8.72)\end{array}$ & $\begin{array}{c}16.36 \\
(8.88)\end{array}$ \\
\hline Firm tenure & $\begin{array}{l}3.70^{* \star *} \\
(3.26)\end{array}$ & $\begin{array}{c}4.78 \\
(4.14)\end{array}$ & $\begin{array}{l}10.37^{4 *} \\
(8.00)\end{array}$ & $\begin{array}{c}12.51 \\
(8.42)\end{array}$ \\
\hline Firm size (logged) & $\begin{array}{l}4.43^{\text {wat }} \\
(1.64)\end{array}$ & $\begin{array}{c}5.12 \\
(1.91)\end{array}$ & $\begin{array}{l}4.49^{+*} \\
(1.69)\end{array}$ & $\begin{array}{c}4.94 \\
(1.74)\end{array}$ \\
\hline Private sector & $\begin{array}{c}.30^{* \star *} \\
(0.46)\end{array}$ & $\begin{array}{c}.45 \\
(0.50)\end{array}$ & $\begin{array}{l}.14^{\text {tw* }} \\
(0.34)\end{array}$ & $\begin{array}{c}.28 \\
(0.45)\end{array}$ \\
\hline Married & $\begin{array}{c}.72 \\
(0.45)\end{array}$ & $\begin{array}{c}.76 \\
(0.43)\end{array}$ & $\begin{array}{c}.74^{4} \\
(0.44)\end{array}$ & $\begin{array}{c}.87 \\
(0.33)\end{array}$ \\
\hline Number of children & $\begin{array}{c}.81^{* * *} \\
(1.04)\end{array}$ & $\begin{array}{c}1.06 \\
(1.08)\end{array}$ & $\begin{array}{l}1.00^{\text {t* }} \\
(1.06)\end{array}$ & $\begin{array}{c}1.47 \\
(1.20)\end{array}$ \\
\hline $\mathbf{N}$ & 200 & 419 & 200 & 540 \\
\hline$(N=1,359)$ & & & & \\
\hline
\end{tabular}

- Means are presented in the first row; standard deviations are in parentheses. Tests are for mean differences by gender.

b In 1000s of Swedish kroner (1 U.S. $\$$ - 6 kroner)

$" \mathrm{p}<.05 \quad * \mathrm{p}<.01 \quad$ **** $\mathrm{p}<.001$ 
TABLE 2: Regression Results for Supervisory Authority

\begin{tabular}{|c|c|c|c|c|c|}
\hline & \multicolumn{3}{|c|}{ Logistic Regression Equations } & \multicolumn{2}{|c|}{ OLS Regression } \\
\hline & Eq. 1 & Eq. 2 & Eq. 3 & Unstd. $\beta$ & Std. $\beta$ \\
\hline Male & $.65^{\star \star *}$ & $.57^{\star \star \star}$ & $.74^{\star *}$ & $.16^{\star \star}$ & .14 \\
\hline Bachelor's degree & -.50 & -.46 & -.15 & -.03 & -.02 \\
\hline M.A. degree & $-.72^{\star \star *}$ & $-.71^{\star \star}$ & -.22 & -.04 & -.04 \\
\hline Ph.D. degree & -.04 & -.04 & .23 & .03 & .02 \\
\hline Age, & $.13^{*}$ & $.14^{\star}$ & $.14^{\star}$ & $.03^{\star}$ & .56 \\
\hline $\mathrm{Age}^{2 a}$ & $-.15^{\star}$ & $-.15^{\star}$ & $-.16^{\star}$ & $-.03^{\star}$ & -.54 \\
\hline Organizational tenure & $.05^{\star}$ & $.05^{\star}$ & $.12^{* m *}$ & .02 的 & .37 \\
\hline Organizational tenure ${ }^{2 a}$ & $-.20^{\star}$ & $-.21^{\star}$ & $-.39 * t$ & -.08 & -.32 \\
\hline Union tenure & $.05^{\star}$ & $.06^{*}$ & $.06^{\star}$ & $.01^{\star}$ & .20 \\
\hline Union tenure ${ }^{2 a}$ & -.12 & -.13 & -.11 & -.02 & -.14 \\
\hline Married & $.40^{\star \star}$ & $.38^{\star}$ & $.38^{\star}$ & $.08^{\star}$ & .06 \\
\hline Number of children & -.05 & -.05 & -.01 & -.00 & -.00 \\
\hline Firm size (Ln) & & $.08^{\star}$ & .02 & .00 & .02 \\
\hline Private sector & & $-.34^{\star \star}$ & -.56 & $-.12^{\star}$ & -.11 \\
\hline
\end{tabular}

The gender gap is not reduced to 0 with these controls. In fact, $42 \%$ of the original gap remains. This adjusted gap is often interpreted as an indicator of discrimination. A similar estimate is obtained from a regression decomposition (data not shown) that takes into account composition, slope and interaction of composition and slope components in arriving at estimates of what is producing the gap (Althauser \& Wigler 1972). About $48 \%$ of the gap may be identified as discrimination. In addition, this decomposition shows the large additive impact of occupational segregation by gender in accounting for differences in access to authority. 
TABLE 2: Regression Results for Supervisory Authority (Continued)

Logistic Regression Equations

$\begin{array}{lll}\text { Eq. } 1 & \text { Eq. } 2 & \text { Eq. } 3\end{array}$
OLS Regression

Unstd. $\beta \quad$ Std. $\beta$

Variable

Professional union ${ }^{\mathrm{b}}$

Agricultural science

Architect

Business administration

Documentation

Lawyer

Physiotherapist

Teacher

General group

Clergy

Other

Medicine

Scientist

Psychologist

Educational director

Social work

Dentistry

University teacher

Gender by private

Gender by teacher

Gender by social work

$\begin{array}{ccr}.06 & .01 & .00 \\ .48 & .10 & .03 \\ .58 & .11 & .04 \\ .72 & .15 & .05 \\ -.04 & -.01 & -.00 \\ .37 & .08 & .02 \\ -2.82^{\star \star \star} & -.52^{\star \star \star} & -.39 \\ -.63 & -.13 & -.03 \\ -.38 & -.08 & -.02 \\ .46 & .10 & .06 \\ .56^{\star} & .11^{\star} & .05 \\ -1.04^{\star} & -.22^{\star} & -.06 \\ -.02 & .00 & .00 \\ 1.30^{\star \star} & .23^{\star \star} & .08 \\ -1.09^{\star \star} & -.24^{\star \star} & -.13 \\ -.42 & -.09 & -.03 \\ -.14 & -.01 & -.00 \\ & & \\ .80^{\star} & .16^{\star} & .16 \\ .82^{\star} & .09^{\star} & .06 \\ 1.16^{\star} & .25^{\star} & .08\end{array}$

Constant

$-2 L L$

$-3.27$

1,757

$-3.54$

$-4.24$

$-.36$

Degrees of freedom

1,346

1,743

1,530

$\mathrm{R}^{2} \mathrm{c}$

.082

1,344

1,327

Adjusted $\mathrm{R}^{2 \mathrm{c}}$

.074

.092

.236

.236

OLS Adjusted gap

.154

.135

.083

.083

Multiplied by 100 .

b The omitted category is engineer.

c Obtained with OLS regression.

$\star p<.05 \quad$ * $p<.01 \quad p<.001$ 
TABLE 3: Regression Results for Monthly Earnings (in Kroner)

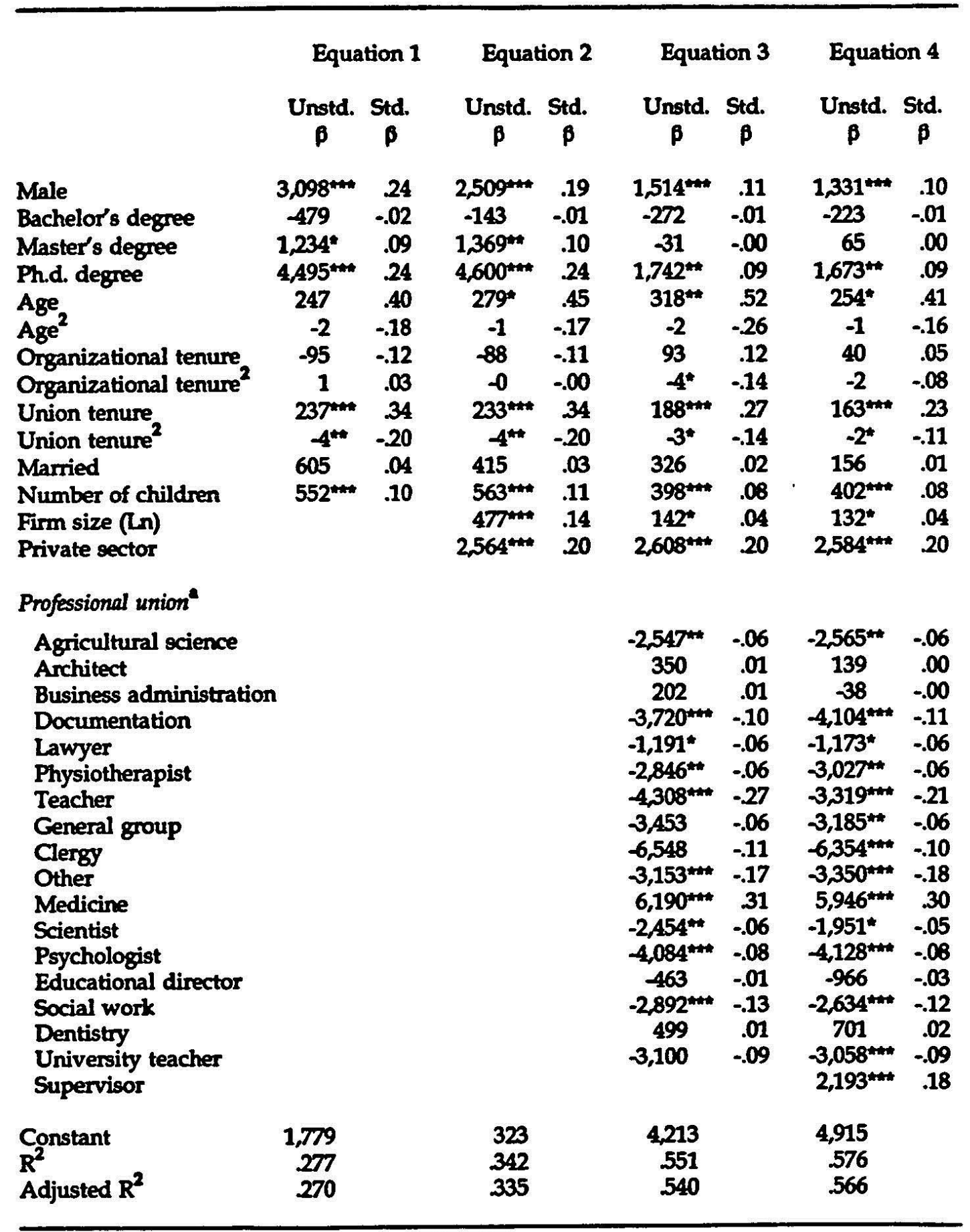

- The omitted category is engineer.

" $p<.05 * p<.01 \quad p<.001$ 


\section{EXPLAINING EARNINGS DIFFERENCES}

Table 3 reports a series of equations for monthly pay that sequentially add meaningful sets of variables up to and including supervisory position. Gender interactions were once again tested for all 31 of the explanatory variables as indicated in equation 4 and there is little evidence of gender interactions. ${ }^{\text {vii }}$ We look at equation 4 for the effects of the explanatory variables. Having a Ph.D. has a fairly large net positive effect on earnings. Experience, as measured by age, has a large constant positive effect. Earnings first increases with union tenure, but then falls off slightly. Although marital status has no effect, having more children at home has a significant positive effect. In addition, the larger the firm in which one is employed, the greater the pay, and those employed in the private sector experience a substantial pay increment. Organizational tenure has no net effect. Finally, there are large net pay differences among the professional unions. ${ }^{\text {ix }}$

As with authority, sequentially controlling on the various sets of variables (equations 1-4) allows us to determine the extent to which the gender earnings gap is explained by gender mean differences on these variables. Looking at the coefficient for the male dummy variable we see the gap is reduced by $20 \%$ when human capital and family variables are controlled (compare the initial gap of 3890 with the coefficient for male in equation 1) and another $15 \%$ when economic structure variables are controlled (equation 2). As with authority, however, it is the worker's profession that has the biggest impact; an additional (and conservative) $25 \%$ of the gap is accounted for (equation 3), even after human capital, family and economic structure variables have been allowed to explain the gap. Including just the professional union dummies first gives the more liberal estimate of the impact of occupational segregation (data not shown) - the reduction of the gap is from 3,890 to 2,323 kroner, or a reduction of $40 \%$. Finally, the fact that women are less often in supervisory positions accounts for an additional $5 \%$ of the original gap (equation 4). In total, then, the unadjusted monthly earnings gap of 3,890 has been reduced by $66 \%$ to 1,331 kroner. This residual ( $34 \%$ of the original gap) is often interpreted as the amount due to discrimination. The regression decomposition (data not shown) identifies a composition component of $69 \%$, which is quite similar to the $66 \%$ obtained here.

\section{Discussion and Conclusions}

The findings from this study are fairly straightforward. Full-time women professionals have only $68 \%$ of the supervisory opportunity that men have and $77 \%$ of the earnings that men have. This greater 
inequality in access to positions of authority was expected because Sweden's equality policies are directed mainly at earnings equalization. A comparison figure for authority access of professionals in the U.S. was not available, but a comparable earnings figure for full-time professional specialties in the U.S. in 1988 is $61.4 \%$ (U.S. Bureau of the Census 1991) and indicates that female professionals in Sweden are not as dramatically disadvantaged in earnings as are their U.S. counterparts.

We found that these gaps in Sweden are not due to differences in how the resources (both human capital and structural) and personal characteristics are translated into access to authority and earnings; Sweden has been largely successful in making the process of attainment similar for men and women. Instead, the gender differences are best understood in additive terms; men more often have resources and are in the structural positions that reward them with high earnings and access to positions of authority. Of these resource and structure differences, occupational segregation by gender plays the largest role in producing gaps favoring men. This finding about occupational segregation is consistent with U.S. data on earnings differences. Jacobs and Lim (1992) review some of the U.S. studies and report estimates of the portion of the earnings gap due to gender segregation of occupations ranging from $17 \%$ to $39 \%$. Our estimate for the effect of occupational segregation among Swedish professionals is similar and ranges from 25 to $40 \%$.

There exist no formal mechanisms in Sweden that channel women into some professions and men into others, and, the stated policy is exactly the opposite. The fact remains, however, that men and women continue to follow gender-typed patterns of employment. There has been some decline in this pattern in Sweden, but it still is high compared to other societies. Using broad occupational categories, Jacobs and Lim (1992) report the index of dissimilarity (proportion of women who would have to change jobs to make their distribution the same as that of men) to be .43 in 1980 for all occupations in Sweden. This has declined from .49 in 1960, but is still relatively high. Comparable values in 1980 for U.S. and Japan were, respectively, .38 and .25 .

The push for gender equality has been fairly recent in Sweden, so traditional beliefs about gender roles are still a part of Swedish culture (Aberg 1987; Ahlqvist 1979). Anderson (1979) reports that specialty in training is rigidly divided by gender; training for manufacturing industry is overwhelmingly the domain of males, whereas females are channeled to training associated with the service sector, health and medical care and the public sector. Also, more women (and even more young women) than men end up in the shorter nonscientific and nontechnical programs of education (Intons-Peterson 1988). Similar gender typed patterns are seen regarding home and household duties (Ahlqvist 1979; Haas 1982; Scott 1982). 
Such data could be interpreted to indicate that women choose different occupations than men because of traditional beliefs and values they hold. Although there likely is some truth to this, such an explanation begs the question because it does not tell us whether these choices are constrained by more subtle, but deeply ingrained, institutional barriers that not only shape these beliefs and values but actually channel and limit career choices. In addition, Tomaskovic-Devey (1993) argues for the importance of status closure and status composition processes in the workplace that produce and perpetuate gender-based segregation in the U.S. It is reasonable to believe that similar processes could be operating in Sweden.

Although occupational segregation is the dominant factor, human capital and family characteristics are also differentially distributed by gender so that women professionals are less often given supervisory authority and have lower earnings than men. However, whereas occupational segregation had the same strong impact on both authority and earnings gender differences, human capital and family variables do not operate exactly the same for authority as for earnings. Experience and tenure variables generally have positive effects on both earnings and access to authority for both men and women, but education increases only earnings. Finding education not to be important in gaining access to positions of authority is consistent with the argument (Kanter 1977; Kluegel 1978; Mueller et al. 1989) that promotions in authority hierarchies are based more on particularistic and vaguely defined criteria other than education and other explicit credentials. The particularistic characteristic of concern here is gender. The large residual ( $42 \%$ of the original gap) captures this gender effect and the vaguely defined criteria (unmeasured) that are used to give men more access to positions of authority.

To conclude, our findings suggest that gender-based discrimination in earnings and authority attainments does exist in the professional ranks in Sweden, being greater for access to positions of authority. However, Sweden's ideology and policy have been somewhat successful in reducing gender inequality. The processes that give access to supervisory authority and produce earnings among professionals are virtually the same for men and women. In addition, relative to U.S. data where the residual for earnings is about $50 \%$ of the original Jacobs \& Lim 1992), the residual gap in Sweden is a relatively small $34 \%$. Occupational segregation by gender is a major factor in producing these gaps. And, because there is occupational heterogeneity within the professional union categories we used, we believe that more detailed occupation measures would account for an even greater portion of the remaining gender gap in both outcome variables and thus produce a lower estimate for the residual that is labeled gender discrimination. This would amplify our main conclusion about the impact of gender- 
based occupational segregation, but also would suggest the importance of continued research on the processes operating to produce this segregation. Occupational segregation by gender appears to be "where the action is" in generating gender inequalities among professionals in Sweden.

\section{References}

Aberg, Rune, Jan Selén and Henrik Tham. 1987. "Economic Resources." Pp. 117-52 in Welfare in Transition: A Survey of Living Conditions in Sweden 1968-1981, edited by Robert Erikson and Rune Aberg. Clarendon Press.

Aberg, Rune. 1987. "Employment and Working Hours." Pp. 78-100 in Welfare in Transition A Survey of Living Conditions in Sweden 1968-1981, edited by Robert Erikson and Rune Aberg. Clarendon Press.

Ahlqvist, Eva-Lena. 1979. "Willing and Able - On Equality between the Sexes on the labor Market." Pp. 76-84 in Labor Markets in Sweden: Facts and Employee Views. The Swedish Institute.

Althauser, Robert P., and Michael Wigler. 1972. "Standardization and Component Analysis." Sociological Methods and Research 198-134.

Andersson, Karl-Olof. 1979. "Education to Prepare for Jobs." Pp. 50-53 in Labor Markets in Sweden: Facts and Employee Views. The Swedish Institute.

Baron, James N., and William T. Bielby. 1985. "Occupational Barriers to Gender Equality." Pp. 233-51 in Gender and the Life Course, edited by Alice S. Rossi. Aldine.

Becker, Gary. 1964. Human Capital. Columbia University Press.

Bielby, William T., and Denise D. Bielby. 1992. "Cumulative Versus Continuous Disadvantage in an Unstructured Labor Market." Work and Occupations 19:366-86.

Blau, Peter M., and Otis Dudley Duncan. 1967. The American Occupational Structure. Wiley.

Brinton, Mary C. 1988. "The Social-Institutional Bases of Gender Stratification: Japan as an Illustrative Case." American Journal of Sociology 94:300-34.

-1989. "Gender Stratification in Contemporary Urban Japan." American Sociological Review 54.549-64.

Davis, Nancy J., and Robert V. Robinson. 1991. "Men's and Women's Consciousness of Gender Inequality: Austria, West Germany, Great Britain and the United States." American Sociological Review 56:72-84.

Erikson, Robert. 1987. "The Class Structure and Its Trends." Pp. 19-42 in Welfare in Transition- A Survey of Living Conditions in Sweden 1968-1981, edited by Robert Erikson and Rune Aberg. Clarendon Press.

Erikson, Robert, and Rune Aberg. 1987. Welfare in Transition: A Survey of Living Conditions in Sweden 1968-1981. Clarendon Press.

Featherman, David L, and Robert M. Hauser. 1976. "Sexual Inequality and Socioeconomic Achievement in the US., 1962-1973." American Sociological Review 41:462-83.

-1978. Opportunity and Change. Academic Press.

Fernandez, John 1975. Black Managers in White Corporations. Wiley. 
Goldthorpe, John H. 1984. "The End of Convergence: Corporatist and Dualist Tendencies in Modem Western Societies." Pp. 315-43 in Order and Conflict in Contemporary Capitalism, edited by John H. Goldthorpe. Oxford University Press.

Haas, Linda. 1982. "Parental Sharing of Childcare Tasks in Sweden." Journal of Family Issues 33:89412.

Hedström, Peter. 1988. Structure of Inequality: A Study of Stratification within Work Organizations. Almqvist \& Wiksell International.

Hodson, Randy. 1989. "Gender Differences in Job Satisfaction: Why Aren't Women More Dissatisfied?" Sociological Quarterly 30:385-99.

Intons-Peterson, Margaret Jean. 1988. Gender Concepts of Swedish and American Youth. Lawrence Erlbaum. Jacobs, Jerry A. 1989a. "Long Term Trends in Occupational Segregation by Sex." American Journal of Sociology 95:160-73. 1989b. Revolving Doors: Sex Segregation and Women's Careers. Stanford University Press. Jacobs, Jerry A., and Ronnie J. Steinberg. 1990. "Compensating Differentials and the MaleFemale Wage Gap: Evidence from the New York State Comparable Worth Study." Social Forces 69:439-68. Jacobs, Jerry A., and Suet Lim. 1992. "Trends in Occupational and Industrial Sex Segregation in 56 Countries, $1960-$ 1980." Work and Occupations 19:450-86.

Kalleberg, Arne L, and Ivar Berg. 1987. Work and Industry. Plenum.

Kanter, Rosabeth Moss. 1977. Men and Women of the Corporation. Basic Books.

Kluegel, James R. 1978. "The Causes and Costs of Racial Exclusion from Job Authority." American Sociological Review 43:285-301.

Loscocco, Karyn, and Arne L. Kalleberg. 1988. "Age and the Meaning of Work in the United Stated and Japan." Social Forces 67"337-56.

Mueller, Charles W., and Toby L. Parcel. 1986. "Ascription, Dimensions of Authority and Earnings: The Case of Supervisors." Pp. 199-222 in Research in Social Stratification and Mobility. Vol. 5, edited by Robert Robinson. JAI Press.

Mueller, Charles W., Toby L. Parcel, and Kazuko Tanaka. 1989. "Particularism in Authority Outcomes of Black and White Supervisors." Social Science Research 18:1-20.

Parcel, Toby L, and Charles W. Mueller. 1983. Ascription and Labor Markets: Race and Sex Differences in Earnings. Academic Press.

Reskin, Barbara F., and Catherine E. Ross. 1992. "Jobs, Authority, and Earnings among Managers" Work and Occupations 19:342-65.

Robinson, Robert V. 1984. "Reproducing Class Relations in Industrial Capitalism." American Sociological Review 49:182-96.

Rosenberg, Samuel. 1989. "Labor Market Restructuring in Europe and the United States: The Search for Flexibility." Pp. 3-16 in The State and the Labor Market, edited by Samuel Rosenberg. Plenum. 
Rosenfeld, Rachel A., and Arne L. Kalleberg. 1990. "A Cross-National Comparison of the Gender Gap in Income." America Journal of Sociology 96:69-106.

Rosenfeld, Rachel A., and Kenneth L Spenner. 1992. "Occupational Sex Segregation and Women's Early Career Job Shifts." Work and Occupations 19:424-49.

Scott, Hilda. 1982. Sweden's "Right to Be Human." M.E. Sharpe.

Tomaskovic-Devey, Donald. 1993. Gender and Racial Inequality at Work. ILR Press.

US. Bureau of the Census. 1991. Consumer Income, Series P-60, No. 172. US. Department of Commerce.

Verba, Sidney, Steven Kelman, Gary Orren, Ichiro Miyake, Joji Watanuki, Ikuo Kabashima, and G. Donald Ferree, Jr. 1987. Elites and the Idea of Equality. Harvard University Press.

Wolf, Wendy C., and Neil Fligstein. 1979. "Sex and Authority in the Workplace: The Cause of Sexual Inequality." American Sociological Review 44"235-52.

Wright, Erik O., and Luca Perrone. 1977. "Marxist Class Categories and Income Inequality." American Sociological Review 42:32-55.

Wright, Erik O., Cynthia Costello, David Hachen, and Joey Sprague. 1982. "The American Class Structure." American Sociological Review 47:709-26.

\footnotetext{
'Verba et al. (1987) refer to Sweden as the "vanguard nation" of the welfare states. Goldthorpe, in his preface to Erikson and Aberg (1987) calls Sweden a "critical" case or even an "awkward" case. For years it was used as the prototype for showing the positive side of a welfare state, while more recently it has been used to illustrate certain negative consequences of social welfare policies. Rosenberg (1989), for example, sees Sweden as out of step with the labor market strategies undertaken by other societies over the last decade. In addition, recent political gains by conservatives suggest problems with the welfare state.

ii In 1947 the Swedish Confederation of Professional Associations (SACO) was formed and in 1975 SACO merged with the National Federation of Civil Servants (SR) to form SACO/SR, which encompasses 25 national unions with more than 300,000 members. This federation has reverted to using SACO as its name. Membership is granted primarily on the basis of a professional or graduate degree in the particular field. Labor relations follow the Swedish model as described above. SACO is known for being more conservative than the other unions and not having an affiliation with the Social Democratic party (Verba et al. 1987). The vast majority of professionals are salaried employees of some firm or agency. Professionals have been attracted to unions in Sweden largely because they administer the unemployment insurance. With the recent loss of power by the liberal Social Democratic party, not only has 570 / Social Forces 73:2, December 1994 the central collective bargaining model broken down, but there are moves to reduce the power of unions.

iii Of the 1995 SACO members who responded in this study $41 \%$ were female, which matches very closely the $42 \%$ figure for female membership in SACO in 1992. The 29A\% females in the sample of 1359 used in the analysis is due primarily to a greater proportion of females working part-time. About $35 \%$ of all professionals (union and nonunion) are females.

iv As will be seen in Table 1 a small proportion of the sample do not have college degrees. The data indicate that many of these are older and were members of the union prior to its establishing rigid education requirements. In addition, jurisdictional issues between SACO and TCO have been solved with regard to criteria other than education.

${ }^{v}$ Although there are a few ambiguities, most of these occupations would be in class I of a three class system devised to identify upper, middle and working classes in Sweden (Erikson 1987). This class has grown from $7.2 \%$ to $9.1 \%$ of the total population from 1968 to 1981 while women's percentage in this class has actually declined from 38.7 to $33.4 \%$ (but has remained the same for professionals in private employment and increased for professionals in public employment [Erikson 1987: Table 3.1]). Finally, because of the small sample sizes in a number of these
} 
unions, an "other" category was formed by combining members of these unions. The union numbers combined were: $5,6,12,14-16,20$, and 25 . No claim is made that this is a homogenous category. It was necessitated entirely by the small sample sizes.

vi Strictly speaking, of course, OLS estimates are inappropriate given the dichotomous dependent variable. However, authority is not highly skewed (see Table 1), making these estimates as well as the adjusted means valuable and not very misleading. Note that the logistic and OLS estimation procedures produce almost identical results about which variables are significant.

vii The adjustment for equation 3 requires that an additive model be used because the covariance adjustment procedure involves adjusting along a common pooled slope for both men and women. Therefore, the adjusted gap was obtained with an equation that did not include the three significant interaction terms.

viii Overall interaction tests were systematically conducted for gender with the variables in each of the four equations. This overall test for equation 1 was not significant. Two interaction terms - (1) men's earnings is increased more by employment in a large firm than is a woman's and (2) organizational tenure actually decreases the pay of a man but has no effect for a woman - were significant in equation 2, but in equations 3 and 4 only one interaction term was significant - being an education director benefits women more than it does men. However, when these two equations were estimated again with just this one interaction term, the interaction was not even close to reaching significance. We conclude from these series of tests that the process that produces earnings for male and female professionals is essentially the same. Additional evidence of this is that the increment in variance explained when the various sets of interaction terms were added was always less than $2 \%$.

ix It is, of course, possible that these union differences represent the strength of the corresponding union in enhancing the reward structure associated with that union rather than differences inherent to the occupations. We believe this is unlikely given the solidaristic wage policy designed to narrow wage differences. Unions have little freedom to bargain for wage levels vastly different from those for other occupations. 